\title{
PREVALENCIA DE TAMBOS INFECTADOS CON EL VIRUS DE LA LEUCOSIS BOVINA (BLV) MEDIANTE DETERMINACIÓN DE ANTICUERPOS EN LECHE POR EL ELISA 108
}

\author{
Mariño, B. ${ }^{1}$, Nogues, M. ${ }^{1}$, Iguzquiza, I. ${ }^{1}$, Gutierrez, S. ${ }^{2}$, \\ Rodriguez, N. ${ }^{2}$, Esteban, e. ${ }^{2}$ \& $\mathbf{O}$ cchi, H. ${ }^{1}$
}

\begin{abstract}
RESUMEN
La leucosis enzoótica bovina (LEB) es una enfermedad infecciosa y contagiosa producida por un retrovirus tipo $\mathrm{C}$, que afecta especialmente a los rodeos lecheros. El objetivo del trabajo fue ampliar los estudios sobre la diseminación del LEB en la zona de influencia de la ciudad de Esperanza, situada a $40 \mathrm{Km}$ de la ciudad de Santa Fe, Argentina. El muestreo fue realizado en el período comprendido entre Agosto-97 a Septiembre-98; en el cual se tomaron muestras de leche de animales en producción, de 26 rodeos tomados al azar que pertenecen al circuito central de control lechero de la Sociedad Rural de las Colonias, Esperanza; haciendo un total de 2324 muestras de leches individuales más las mezclas de leche de cada establecimiento. Las muestras fueron procesadas por medio del test de ELISA de bloqueo 108 en leche.

De los datos obtenidos surgen los siguientes resultados, de los 26 establecimientos muestreados, el $84 \%$ fueron positivos, incluyendo las mezclas de leche.

Este trabajo demuestra el alto porcentaje de vacas lecheras infectadas en el área de estudio, y la necesidad de incrementar programas de control a través de la identificación de animales positivos por técnicas confiables y económicas para evitar un impacto sanitario y económico en la región.

Palabras clave: leucosis enzoótica bovina, anticuerpos en leche, test de ELISA.
\end{abstract}

\section{SUMMARY}

\section{Prevalence of dairy herds infected eith Bovine Leucosis virus (BLV) by means of the determination of milk antibodies by Elisa 108.}

The Enzootic Bovine Leukosis (LEB) is a disease caused by a type-C retrovirus that specially affects to milking farms. The goal of this study was to contribute to the knowledge about the dissemination of this LEB virus into the influence zone in the city of Esperanza, $40 \mathrm{~km}$ from Santa

1.- Facultad de Ciencias Veterinarias, UNL. Kreder 2805. (3080) Esperanza, provincia de Santa Fe. Tel: (03496) 420639.

2.- Laboratorio de Virología, Departamento SAMP. Facultad de Ciencias Veterinarias (UNCPBA). Pinto 399. (7000) Tandil, provincia de Buenos Aires.

Manuscrito recibido el 12 de febrero de 2003 y aceptado para su publicación el 2 de marzo de 2004. 
Fe, Argentina. Fieldwork was conducted between Ago-97 and Sep-98, in the central circuit of milk control (Sociedad Rural de las Colonias) of Esperanza. Samples of milk were taken at random from 26 farms giving a total of 2324 individual samples. Data were analyzed by Eliza test 108 in milk (m 108) FCV-UCPBA. 22 farms ( $86 \%$ from the total) were positive including the pools of milk. Since this represents a high degree of infection, new programs of control are required in order to prevent the occurrence of any sanitary or economical impact in this region.

Key words: Enzootic Bovine Leukosis, antibodies in milk, Elisa test. 